\title{
Effect of ultrasound on the functional and structural properties of hydrolysates of different bovine collagens
}

\author{
Alessandra Roseline VIDAL ${ }^{1}$, Rogério Luis CANSIAN² ${ }^{2}$ Renius de Oliveira MELLOํㅛ (D), Ernesto Hashime KUBOTA ${ }^{1}$, \\ Ivo Mottin DEMIATE³ ${ }^{3}$ Acácio Antonio Ferreira ZIELINSKI³ ${ }^{3}$ Rosa Cristina Prestes DORNELLES ${ }^{1 *}$
}

\begin{abstract}
The ultrasound effect on functional and structural properties of hydrolysates of different bovine collagens (fibers, gelatines and hydrolysates) was evaluated. The enzymatically hydrolyzed samples (enzyme Alcalase ${ }^{\circledR}$ ) with previous or simultaneous ultrasound treatment presented higher number of bands with shorter wavelengths (mid-FTIR). The ultrasound provided the samples with a higher hydrolysis degree and favored the antimicrobial activity, evidencing the advantages of its use in the process. Results revealed that higher hydrolysis degree does not always result in higher antioxidant activity. The use of ultrasound in the hydrolysis of these samples was seen to be effective, providing them with higher functionality and structural disruption.
\end{abstract}

Keywords: protein hydrolysis; antioxidant activity; antimicrobial activity; infrared spectroscopy; ultrasound.

Practical Application: The hydrolysis providing better functionality to the different bovine collagen hydrolysates.

\section{Introduction}

When applying the ultrasound, the sound wave goes through the medium causing a series of effects; changes in the heat and mass transportation phenomena are among them. These effects are explained by several associated mechanisms that might vary depending on the environment in which the acoustic wave propagates (Cárcel et al., 2012), thus, allowing the modification of products or processes (Tao \& Sun, 2015). Recent studies have shown that the ultrasound can change the structure and functional properties of food protein (Arzeni et al., 2012; Ashokkumar, 2015; Vidal et al., 2018), mainly those from animal origin (O'Sullivan et al., 2015). It might cause increase in the enzymatic activity due to better substrate-enzyme bonding and the exposure to the enzyme active site. When used as pre-treatment or simultaneously during the hydrolysis process, it affects the hydrogen bonds and hydrophobic interactions, breaking the protein tertiary and quaternary structures due to cavitation effects (Vidal et al., 2018). These structural changes enable the enzyme access to the structure, increasing the hydrolysis and bioactivity degree (Ozuna et al., 2015).

There is growing interest in the processes of collagen extraction and its by-products (Decker \& Park, 2010) due to the possibility of using this protein to substitute synthetic agents in the most diverse industrial processes and also for allowing higher valuation of by-products of the slaughtering of animals for food. Collagens form a large and diversified family of proteins thatare found in all multicellular organisms conjunctive tissues, mainly in tendons, cartilages, ligaments, muscles, demineralized bones, vascular system and other organs from vertebrates (Liu et al.,
2010). It is the animal origin protein found in the largest amounts and represents nearly $30 \%$ of the total protein (Pati et al., 2010).

From the mid 2000 on, studies started to appear that sought the acquisition, fractioning and characterization of collagen hydrolysates and peptides (Decker \& Park, 2010) aiming at evaluating some functional properties of those compounds. The collagen derived peptides can be obtained through enzymatic hydrolysis using animal or vegetable proteases (Goméz-Guillén et al., 2011) applied to the by-product of animal slaughtering resulting in aggregated value (Di Bernardini et al., 2011). The collagen peptides might present antimicrobial, antioxidant and anti-hypertensive activities (Li et al., 2007; Herregods et al., 2011).

The differences between the several types of collagen by-products (gelatin, fiber and hydrolyzed collagen) and the evaluation of ultrasound effects on the enzymatic hydrolysis, functional and structural properties of protein hydrolysates have not been fully explored and represent a wide field to be investigated (Vidal et al., 2018). The objective of this study was to evaluate the effect of ultrasound on the functional and structural properties of hydrolysates of different bovine collagens.

\section{Materials and methods}

The different types of bovine collagen used to obtain protein hydrolysates are presented in Table 1 . The Alcalase $2.4 \mathrm{~L}^{\circledR}$ (Novozymes $^{\circledR}$ ) was supplied by the company Tovanni Benzaquen Ingredientes (São Paulo, SP, Brazil) and all the agents were of analytical degree, purchased from Sigma-Aldrich Brasil Ltda (São Paulo, SP, Brazil). 
Table 1. Different types of bovine collagen used to obtain protein hydrolysates.

\begin{tabular}{|c|c|c|c|}
\hline Type of collagen & Name/Code & Manufacturer & Description \\
\hline Natural fiber & Fiber/FB & $\begin{array}{l}\text { Novaprom Food Ingredients } \\
\text { Ltda (Lins - SP - Brazil) }\end{array}$ & $\begin{array}{l}\text { Particle size between } 1.80 \text { and } 1.92 \mathrm{~mm} \text {, extracted from bovine skin through } \\
\text { alkaline treatment, } \mathrm{pH} \text { between } 7 \text { and } 9.5\end{array}$ \\
\hline Powder fiber & Powder fiber/FP & $\begin{array}{l}\text { Novaprom Food Ingredients } \\
\text { Ltda (Lins - SP- Brazil) }\end{array}$ & $\begin{array}{l}\text { Particle size between } 0.45 \text { and } 0.57 \mathrm{~mm} \text {, extracted from bovine skin through } \\
\text { alkaline treatment, pH between } 7 \text { and } 9.5\end{array}$ \\
\hline Gelatin 1 & Gelita $^{\circledR} /$ GEL & $\begin{array}{l}\text { Gelita do Brasil Ltda } \\
\text { (Cotia - SP- Brazil) }\end{array}$ & $\begin{array}{l}\text { Extracted from leather or diverse raw material through alkaline partial } \\
\text { hydrolysis (rigorous treatment), } 236 \mathrm{~g} \text { Bloom; } 40 \mathrm{mP} \text { viscosity; } 11 \% \\
\text { humidity; } \mathrm{pH} 5.6 ;<=2 \% \text { ashes }\end{array}$ \\
\hline Hydrolysate 1 & Peptan ${ }^{\circledR} /$ PEP & $\begin{array}{l}\text { Rousselot Gelatinas do Brasil } \\
\text { Ltda (Amparo - SP- Brazil) }\end{array}$ & $\begin{array}{l}\text { Extracted from bovine leather/ swine skin through chemical + enzymatic } \\
\text { hydrolysis, } 4 \mathrm{mP} \text { viscosity; } 7.2 \% \text { humidity; } 92.15 \% \text { protein; } \mathrm{pH} \text { 6; } 0.65 \% \text { ashes }\end{array}$ \\
\hline Hydrolysate 2 & Peptiplus $^{\circledR} /$ PTL & $\begin{array}{l}\text { Gelita do Brasil Ltda } \\
\text { (Cotia - SP- Brazil) }\end{array}$ & $\begin{array}{l}\text { Extracted from bovine leather/swine skin through chemical + enzymatic } \\
\text { hydrolysis, } 39 \mathrm{mP} \text { viscosity; } 5.9 \% \text { humidity; } 92.1 \% \text { protein; } \mathrm{pH} 5.7 ;<=2 \% \text { ashes }\end{array}$ \\
\hline
\end{tabular}

\subsection{Physical-chemical characterization of collagens}

The following physicochemical analyses were performed to characterize the collagens: $\mathrm{pH}$ (electrometric determination), lipids (direct extraction in Soxhlet), proteins (modified Kjedahl method), moisture (at $105{ }^{\circ} \mathrm{C}$ ), ashes (burning at $550{ }^{\circ} \mathrm{C}$ ), hydroxyproline (spectrophotometry) and collagen (correction factor 8.0), according to AOAC (2016).

\subsection{Hydrolysis procedures}

The different treatments employed to obtain bovine collagen protein hydrolysates are presented in Table 2 . The enzymatic reactions were carried out following the methodology used by Schmidt \& Salas-Mellado (2009) with some changes, in which $8 \%$ enzyme was tested in relation to the substract. The following equipment was used for the hydrolysis reactions: ultra thermostatic bath (Model SL152, power 2000 W, SOLAB, Piracicaba, SP, Brazil), ultrasonic bath (Model ECO-SONICS - Q3.8/40A, power $88 \mathrm{~W}$ and frequency $40 \mathrm{KHz}$, ULTRONIQUE, SERVYLAB, São Leopoldo, RS, Brazil) and a COLEMAN centrifuge (Model 90 - 1, Santo André, SP, Brazil). The hydrolysates were freeze-driedin a TERRONI lyophilizer (Model LS3000, São Carlos, SP, Brazil). For the EHU treatment, the hydrolysis process total time was two hours, while for the UEH this time was four hours.

\subsection{Structural characterization of collagen hydrolysates}

FTIR analysis was performed according to the methodology described by Demiate et al. (2000). A Fourier-transform infrared spectrophotometer (FTIR) Shimadzu IR Prestige-21 (Shimadzu Corporation, Kyoto, Japan) was used and the spectra collected in the range $4000-400 \mathrm{~cm}^{-1}$. Pellets were produced by mixing $100 \mathrm{mg}$ of $\mathrm{KBr}$ and $2 \mathrm{mg}$ of lyophilized sample and using a carver hydraulic press.

\subsection{Determination of the collagen hydrolysate hydrolysis degree}

The modified biuret method was used to determine the hydrolysis degree, as suggested by Di Bernardini et al. (2012). The bovine albumin (Sigma-Aldrich Brasil Ltda, São Paulo, SP,
Table 2. Treatments used to obtain bovine collagen protein hydrolysates.

\begin{tabular}{cl}
\hline Code & \multicolumn{1}{c}{ Treatment description } \\
\hline CC & Crude collagen \\
HU & Ultrasound hydrolysis \\
EH & Enzymatic hydrolysis \\
EHU & Ultrasound assisted enzymatic hydrolysis \\
UEH & Previously treated with ultrasound followed by enzymatic \\
& hydrolysis \\
\hline
\end{tabular}

Brazil) was used as standard for the method. The hydrolysis degree was calculated based on the amount of protein in the crude collagens (Equation 1).

$$
D H=\left(\frac{P I-P F}{P I}\right) \times 100
$$

Where, $D H$ =hydrolysis degree; $P I=$ crude sample protein; $P F=$ sample protein after hydrolysis.

\subsection{Determination of the collagen hydrolysate antioxidant activity}

The antioxidant activity was evaluated by the DPPH method (Brand-Williams et al., 1995), modified by Sánchez-Moreno et al. (1998) to measure the kinetic parameters. A UV spectrophotometer was used (Model UV - M51, BEL Photonics, SERVYLAB, São Leopoldo, RS, Brazil).

\subsection{Determination of the collagen hydrolysate antimicrobial activity}

The Minimal Inhibitory Concentration (MIC) was determined by the indirect method of bacterial growth [Gram-negative (Salmonella choleraesuis - ATTC 10708) and Gram-positive (Staphylococcus aureus - ATTC 6538)] in liquid medium (Gaio et al., 2015). The MIC values were determined as triplicate runs. An amount of $10 \mu \mathrm{L}$ pre-inoculum $\left(10^{8} \mathrm{CFU} \mathrm{mL}^{-1}\right)$ was used to inoculate $\mathrm{LB}$ medium ( $10 \mathrm{~g} \mathrm{~L}^{-1}$ tryptone, $5 \mathrm{~g} \mathrm{~L}^{-1}$ yeast extract, and $5 \mathrm{~g} \mathrm{~L}^{-1}$ sodium chloride) and different concentrations 
of collagen hydrolysate formulations diluted in sterile water. The bacterial growth was determined as the difference between the absorbance at 0 and after $24 \mathrm{~h}$ of incubation.

\subsection{Statistical analysis}

The collagen physicochemical analysis results were submitted to the univariate variance analysis - ANOVA and compared by Tukey test at $5 \%$ significance level usingthe software Action ${ }^{\circledR} 2.9$ (Estatcamp, São Carlos, SP, Brazil).

After collecting the FTIR spectra, they were smoothed (15 points), the baseline was corrected and $\mathrm{CO}_{2}$ zone removed and also the data was normalized, using the Shimadzu IRsolution 1.40 software. Then, a table with all data was constructed using the wavelength as column and the samples as lines. A chemometric approach including principal component analysis (PCA) was implemented in the Pirouette v. 4.0 (Infometrix ${ }^{\circledR}$, Bothell, WA, USA). The analysis was performed in the spectrum region ranging from 500 to $1722 \mathrm{~cm}^{-1}$, and dataset was mean-centered and submitted to $1^{\text {st }}$ derivate. PCA is a data reduction technique that was applied to verify the difference and to extract important information from FTIR spectra between the samples, and a three-dimensional scatter plot was built to project the samples (Zielinski et al., 2014).

Two experiments were performed for the statistical data evaluation regarding protein (biuret), hydrolysis degree (biuret) and antioxidant activity (DPPH):

Experiment 1 was developed to evaluate which ultrasound application, previous or simultaneous, would be more effective in the enzymatic treatment. The experimental analysis was performed in split plot with a completely randomized design; the different collagens were distributed in the whole plots and ultrasound application (previous vs. simultaneous) and their interaction distributed randomly in the subplots within each plot, according to the statistical model (Equation 2):

$Y_{i j k}=\mu+\alpha_{i}+(\alpha \gamma)_{i k}+\beta_{j}+(\alpha \beta)_{i j}+\varepsilon_{i j k}$

where, $Y_{i j k}$ value observed in the $i^{\mathrm{h}}$ whole plot, $k^{\mathrm{h}}$ repetition, and $j^{\mathrm{h}}$ subplot; $\mu$ overall mean of the response variable; $\alpha_{i}$ fixed effect of $i^{\mathrm{h}}$ collagen; $(\alpha \gamma)_{i k}$ residual effect of whole plot (error A); $\beta_{j}$ fixed effect of $j^{\text {h }}$ ultrasound application; $(\alpha \beta)_{i j}$ fixed effect of interaction between $i^{\mathrm{h}}$ collagen and $j^{\mathrm{h}}$ ultrasound application; $\varepsilon_{i j k}$ residual effect of the subplots (error B) or random effect associated to $i j k^{\mathrm{h}}$ observation, supposed $\varepsilon_{i j k \sim}^{i \text { id }} N\left(0, \sigma^{2}\right)$ Experiment 2 was performed to evaluate the collagen effect, enzymatic concentration and the use of ultrasound or not. The experiment analysis was developed in split plot with completely randomized design, and different collagens were distributed in the whole plots, enzyme concentrations (0 and $8 \%)$ and ultrasound application or not (without US vs. with simultaneous US) and their interactions randomly distributed in the subplots within each plot, according to the statistical model described in Equation 3:

$Y_{i j k l=} \mu+\alpha_{i}+(\alpha \delta)_{i l}+\beta_{j}+\gamma_{k}+(\beta \gamma)_{j k}+(\alpha \beta)_{i j}+(\alpha \gamma)_{i k}+(\alpha \beta \gamma)_{i j k}+\varepsilon_{i j k l}(3)$

where, $Y_{i j k l}$ value observed in $i^{\mathrm{h}}$ whole plot, $l^{\mathrm{h}}$ repetition and $j k^{\mathrm{h}}$ subplot; $\mu$ overall mean of the response variable; $\alpha_{i}$ fixed effect of $i^{\mathrm{h}}$ collagen; $(\alpha \delta)_{i j}$ residual effect of whole plot (error A); $\beta_{j}$ fixed effect of $j^{\text {h }}$ enzymatic concentration; $\gamma_{k}$ fixed effect of $k^{\mathrm{h}}$ ultrasound application; $(\beta \gamma)_{j k}$ fixed effect of the interaction between $j^{\mathrm{h}}$ enzymatic concentration and $k^{\mathrm{h}}$ ultrasound application; $(\alpha \beta)_{i j}$ fixed effect of the interaction between $i^{\mathrm{h}}$ collagen and $j^{\mathrm{h}}$ enzymatic concentration; $(\alpha \gamma)_{i k}$ fixed effect of the interaction between $i^{\mathrm{h}}$ collagen and $k^{\mathrm{h}}$ ultrasound application; $(\alpha \beta \gamma)_{i j k}$ fixed effect of the interaction between $i^{\mathrm{h}}$ collagen, $j^{\mathrm{h}}$ enzymatic concentration and $k^{\mathrm{h}}$ ultrasound application; $\varepsilon_{i j k l}$ residual effect of the subplots (error B) or random effect associated to $i j k l^{\mathrm{h}}$ observation, supposed $\varepsilon_{i j k l \sim}$ iid $N\left(0, \sigma^{2}\right)$ The resulting data were submitted to the investigation of outliers from the studentized residue. Later on, they were submitted to the univariate variance analysis (ANOVA) through the GLM procedure; the averages were adjusted through the ordinary least squares using LSMEANS statement and compared by t test at $5 \%$ significance level. In addition, the Spearman correlation analysis between the variables under study was done. The statistical analyses were performed using $\mathrm{SAS}^{\circledR}$ System for Windows" version 9.4 (SAS Institute Inc., Cary - NC, USA).

\section{Results and discussion}

\subsection{Collagen physicochemical characterization}

There was significant difference $(\mathrm{p}<0.05)$ for moisture, ashes, proteins, lipids, $\mathrm{pH}$, hydroxyproline and collagen in the different crude collagen samples (Table 3). The GEL and ROU samples presented the highest moisture values, which is explained by the different drying process of those collagens during industrial processing. Regarding ashes, the sample that presented the highest content was FP, while the other samples had similar values. The ash content variation between different

Table 3. Humidity, ashes, proteins, lipids, $\mathrm{pH}$, hydroxyproline and collagen average content regarding the different types of collagen.

\begin{tabular}{|c|c|c|c|c|c|c|c|}
\hline $\begin{array}{l}\text { Type of } \\
\text { collagen }^{*}\end{array}$ & $\begin{array}{c}\text { Humidity } \\
(\%)\end{array}$ & $\begin{array}{c}\text { Ashes } \\
(\%)\end{array}$ & $\begin{array}{c}\text { Proteins } \\
(\%)\end{array}$ & $\begin{array}{c}\text { Lipids } \\
(\%)\end{array}$ & $\mathrm{pH}$ & $\begin{array}{c}\text { Hydroxyproline } \\
\mathrm{g} / 100 \mathrm{~g}^{\star *}\end{array}$ & $\begin{array}{c}\text { Collagen } \\
\mathrm{g} / 100 \mathrm{~g}\end{array}$ \\
\hline FB & $0.96^{\mathrm{b}}+0.39$ & $1.24^{\mathrm{b}}+0.77$ & $87.7^{\mathrm{b}}+0.43$ & $3.37^{a}+0.01$ & $6.72^{a}+0.02$ & $10.8^{\mathrm{b}}+0.06$ & $86.3^{\mathrm{b}}+0.51$ \\
\hline FP & $3.51^{\mathrm{ab}}+0.12$ & $3.20^{\mathrm{a}}+2.29$ & $84.4^{c}+0.85$ & $3.14^{\mathrm{b}}+0.06$ & $6.26^{c}+0.02$ & $11.3^{\mathrm{b}}+0.16$ & $90.6^{\mathrm{b}}+1.24$ \\
\hline PEP & $7.59^{\mathrm{ab}}+0.09$ & $0.72^{\mathrm{b}}+0.28$ & $87.3^{\mathrm{b}}+0.28$ & $0.53^{c}+0.03$ & $6.46^{\mathrm{b}}+0.01$ & $11.4^{\mathrm{b}}+0.28$ & $91.2^{\mathrm{b}}+2.26$ \\
\hline PTL & $5.51^{\mathrm{ab}}+0.51$ & $0.57^{\mathrm{b}}+0.21$ & $91.0^{\mathrm{a}}+0.29$ & $0.58^{c}+0.01$ & $5.62^{\mathrm{d}}+0.02$ & $12.9^{\mathrm{a}}+0.04$ & $100.0^{\mathrm{a}}+0.34$ \\
\hline GEL & $10.6^{\mathrm{a}}+0.09$ & $0.56^{\mathrm{b}}+0.22$ & $86.3^{\mathrm{bc}}+0.54$ & $0.53^{c}+0.01$ & $5.60^{\mathrm{d}}+0.03$ & $12.9^{\mathrm{a}}+0.14$ & $100.0^{\mathrm{a}}+1.13$ \\
\hline ROU & $10.6^{\mathrm{a}}+5.09$ & $0.61^{\mathrm{b}}+0.13$ & $86.3^{b c}+0.80$ & $0.54^{c}+0.03$ & $5.35^{\mathrm{e}}+0.02$ & $11.4^{\mathrm{b}}+0.15$ & $91.2^{\mathrm{b}}+1.19$ \\
\hline
\end{tabular}

Averages in the same column with different overwritten letters differed significantly one from another in the Tukey test ( $<<0.05)$. ${ }^{*} \mathrm{FB}-\mathrm{collagen}$ natural fiber; FP - powder collagen fiber; PEP - hydrolyzed 1 collagen; PTL - hydrolyzed 2 collagen; GEL - gelatin 1; ROU - gelatin 2. ${ }^{*}$ Values informed by the companies that manufactured the samples. 
samples can be explained by the different types of raw materials used to extract the collagens.

Analyzing the protein content, the sample PTL presented the highest value while the sample FP presented the lowest value. The collagen protein content is affected by the extraction method; the most rigorous extraction processes result in lower protein content, since they affect severely the protein structure, breaking it into smaller fractions. In this study, high protein content was found in the collagen hydrolysates, agreeing with the study of Sila et al. (2016), in which a fish (Barbus barbus) protein hydrolysate presented high protein content $(81.43 \pm 0.73 \%)$. That fact was ascribed to its solubilization during hydrolysis, the removal of non protein substances and the partial removal of lipids after hydrolysis.

When the lipid average values were analyzed, the FB sample was seen to present the highest content, followed by the FP sample. The FB and FP production process generates higher fat residual values. Pre-treatment is not as drastic as the gelatin industry because the goal is to get raw material (fiber and fiber powder). The FB sample presented the highest $\mathrm{pH}$ value. The collagen final $\mathrm{pH}$ depends on the phases used in the extraction process. This $\mathrm{pH}$ close to neutrality reflects a $\mathrm{pH}$ correction phase (neutralization) in the FB sample extraction process.

One of the amino acids responsible for keeping the stability of the triple helix (collagen secondary structure) is hydroxyproline. Its absence or low concentration in the collagen results in the loss of the triple helix conformation when submitted to high temperatures (Goméz-Guillén et al., 2011), thus hampering the gelation properties. The collagen samples presenting the highest hydroxyproline and collagen contents were the PTL and GEL. These samples presented almost the same contents for both analyses, probably because they were produced by the same company and, consequently, obtained from the same raw material. However, they were submitted to different extraction treatments, chemical and enzymatic hydrolysis and alkaline partial hydrolysis, respectively.

\subsection{Bovine collagen hydrolysates structural characterization}

The infrared spectroscopy is one of the oldest and most used experimental analyses to investigate the secondary structure of polypeptides and proteins (Kong \& Yu, 2007). The principal component analysis (PCA) results indicated that the samples were separated into four distinct groups according to the band similarity (Figure 1) explaining $85.57 \%$ of the data variance.

In a study by Duan et al. (2014) the Fourier transform infrared spectroscopy was used seeking to verify the secondary structure conformational prediction of egg transferrin purified peptide. Results suggested that the peptide conformation was based on $\beta$-leaves. The samples enzymatically hydrolyzed with previous or simultaneous ultrasound presented higher number of bands in wavelength $\left(\mathrm{cm}^{-1}\right)$ than those that had only been hydrolyzed with enzyme or ultrasound, indicating that this technology strengthened these samples hydrolysis process. What can be inferred is that each type of collagen requires a specific hydrolysis treatment, which does not have the same effect on samples with different properties as a result of the processes used to obtain these collagens.

\subsection{Results of the previous or simultaneous ultrasound effect to the enzymatic hydrolysis process}

The collagen effect and the interaction collagen vs. ultrasound was seen to be significant $(p<0.05)$ for the variables protein (ptn), hydrolysis degree (DH) and for the antioxidant activity (AA) (results not shown). The ultrasound effect was significant $(p<0.01)$ for the variables protein and antioxidant activity. Similar results were found by Vidal et al. (2018) but with the use of pepsin. The ultrasound effect on the hydrolysis of different bovine collagens, according to their application, might inhibit or not the enzymatic activity, depending on the conditions imposed to the medium.

As it had been expected, there was negative correlation $(p<0.001)$ between the protein $(p t n)$ values and the hydrolysis degree $(\mathrm{DH})(\mathrm{r}=-0.84)$ (results not shown). The highest residual protein content (after the hydrolysis process) resulted in lower hydrolysis degree. This fact might be explained by the lower enzyme action during the hydrolysis process, which might have been affected negatively by the ultrasound, the excessive amount of enzyme in the medium (enzyme excess inhibition) and scarcity of substrate. There was positive correlation $(\mathrm{p}<0.01)$ between the protein values and the antioxidant activity $(\mathrm{r}=0.46)$.

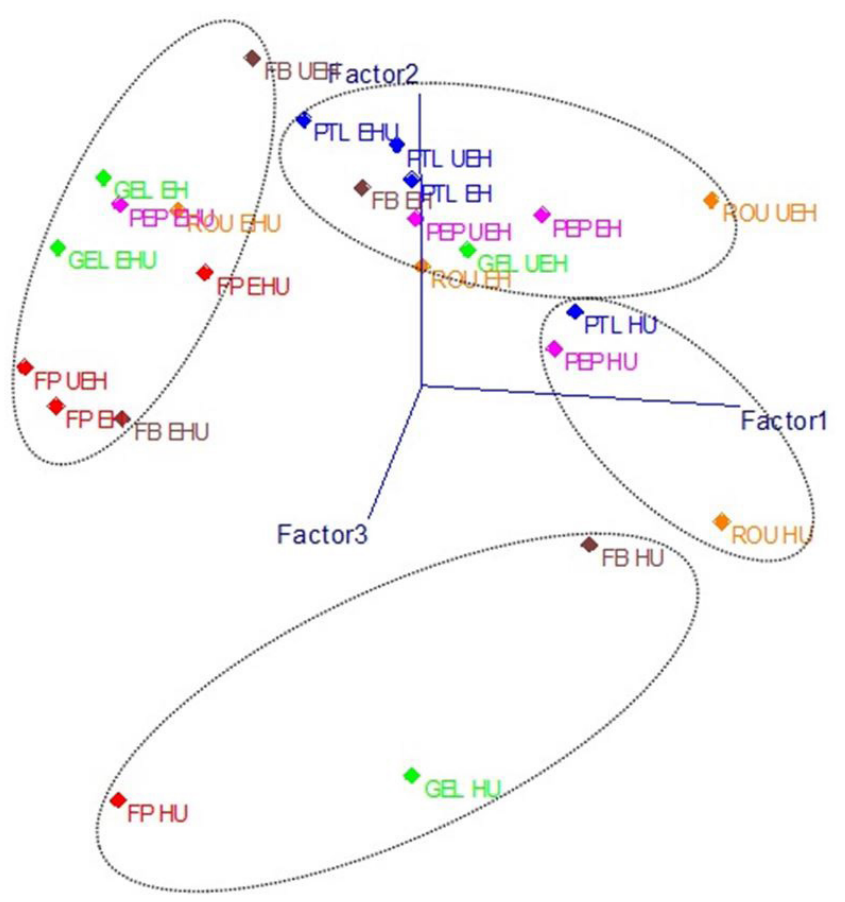

Figure 1. 3D-scatter plot obtained through PCA based on the 1722 to $500 \mathrm{~cm}^{-1}$ region.

FB - collagen natural fiber; FP - powder collagen fiber; PEP - hydrolyzed 1 collagen; PTL - hydrolyzed 2 collagen; GEL - gelatin 1; ROU - gelatin 2; $\mathrm{HU}$ - ultrasound hydrolysis; EH - enzymatic hydrolysis; EHU - ultrasound assisted enzymatic hydrolysis; UEH - previously treated with ultrasound followed by enzymatic hydrolysis. 


\subsection{Average total results for protein (PTN), hydrolysis degree $(D H)$ and antioxidant activity $(A A)$ in the evaluation of previous or simultaneous ultrasound effect on the enzymatic hydrolysis process}

The results presented are the average total protein, degree of hydrolysis and antioxidant activity for all collagen analyzed because the objective was to find out if the use of ultrasound was better before or during hydrolysis. The use of ultrasound simultaneously to the enzymatic hydrolysis process generated lower protein content, when compared to the previous use of ultrasound. Consequently, the hydrolysis degree for simultaneous ultrasound treatment was higher than that of the previous ultrasound treatment (Table 4). These results corroborate with Vidal et al. (2018) however different results were found by Yu et al. (2014), who verified that the ultrasound application $(278.8 \pm 7.4 \mathrm{~W}, 40 \mathrm{kHz})$ for 30-60 minutes, at $0-4{ }^{\circ} \mathrm{C}$ controlled temperature inhibited the $\alpha$-amylase and papain enzyme activity. By contrast, using the same process conditions, the pepsin activity was activated. Those effects were ascribed to alterations in their secondary and tertiary structures. In another study, the same authors evaluated the ultrasound influence in the tyrosinase activity and the results showed increase in the enzyme activity caused by better bonding substrate-enzyme and the exposure to the enzyme active site (Yu et al., 2013).

The antioxidant activity was higher in samples hydrolyzed with $8 \%$ enzyme and simultaneous ultrasound. Opposite result was found by Knezevic-Jugovic et al. (2012), who compared the effects of ultrasound and high pressure processing with carbon dioxide on the egg white protein proteolytic hydrolysis and the antioxidant activity of the hydrolysates obtained. The results found by those authors revealed that the combination of previous ultrasound treatment ( 1 hour, $30 \mathrm{kHz}, \mathrm{pH} 8.3$ ) and the subsequent enzymatic hydrolysis with Alcalase $\left(50{ }^{\circ} \mathrm{C}\right.$ and $\left.\mathrm{pH} 8.0\right)$ increased the antioxidant activity of the hydrolysates.

To evaluate the effect of different types of collagen, the enzyme and the ultrasound on the different variables under analysis, the simultaneous ultrasound was chosen as treatment, since it resulted in lower protein content, higher hydrolysis degree and higher antioxidant activity.

Table 4. Average results of protein, hydrolysis degree and antioxidant activity in collagen hydrolysate samples, evaluating the ultrasound effect on the enzymatic hydrolysis.

\begin{tabular}{ccc}
\hline & \multicolumn{2}{c}{ Ultrasound } \\
\cline { 2 - 3 } ptn, $\mathbf{m g} / \mathbf{m L}$ & Previous & Simultaneous \\
$\mathbf{D H}, \%$ & $8.10^{\mathrm{a}}$ & $7.85^{\mathrm{b}}$ \\
$\mathbf{A A}, \%$ & $3.40^{\mathrm{a}}$ & $3.68^{\mathrm{a}}$ \\
\hline
\end{tabular}

ptn - protein; DH - hydrolysis degree and AA - antioxidant activity. Averages on the same line with small different letters indicate significant difference between ultrasound with "t" test $(\mathrm{p}<0.05)$.
3.5 Probabilistic values of ultrasound effect (simultaneous), enzyme ( 0 and $8 \%$ ) and the different types of collagen for protein, hydrolysis degree and antioxidant activity

The effect of the interaction collagen $\mathrm{x}$ enzyme $\mathrm{x}$ ultrasound was significant $(p<0.05)$ for all variables, that is, the variations in their average values are directly linked to the type of collagen, enzyme percentage and use of ultrasound or not in the hydrolysis process, which might affect directly the functionality of the peptide generated in the hydrolysis (results not shown).

There was negative correlation $(\mathrm{p}<0.001)$ between the protein and hydrolysis degree $(r=-0.56)$ values (results not shown). Protein and antioxidant activity values did not present correlation $(\mathrm{p}>0.05)(\mathrm{r}=-0.05)$. The hydrolysis degree and antioxidant activity values presented positive correlation $(\mathrm{p}<0.01)(\mathrm{r}=0.35)$, that is, higher hydrolysis degree resulted in higher antioxidant activities.

\subsection{Average results for protein and hydrolysis degree in different samples of collagen hydrolysates under the effect of ultrasound vs. enzyme vs. collagen interaction}

The FB crude sample presented $8.21 \mathrm{mg} / \mathrm{mL}$ protein average value, but when it was ultrasound treated its protein content dropped to $7.24 \mathrm{mg} / \mathrm{mL}$, representing a $12.15 \%$ hydrolysis degree (Table 5). The decrease in protein value was provoked by the medium cavitation, which provokes breakage of the protein structure, generating smaller fractions.

Giménez et al. (2009) also pointed out the hydrolysis degree used in the Alcalase enzyme process. They carried out the hydrolysis of flounder and squid gelatin samples at $50{ }^{\circ} \mathrm{C}$ for three hours, and obtained hydrolysis degree ranging from 35 and $50 \%$.

The FP sample presented the highest protein content, probably for being a crude sample, without having been submitted to any previous hydrolysis process. The PTL sample presented low protein content and, consequently, one of the highest hydrolysis degree values along with the FB sample; despite having been submitted to the hydrolysis process, this demonstrates that it was more bioavailable to the enzymatic hydrolysis process and that the ultrasound favored this process. The GEL and ROU samples, despite having presented low protein values, did not present hydrolysis degree values as high as expected, representing the lowest values found for these samples.

The enzyme specific activity is related to the hydrolysis degree, that is, the higher the enzyme activity the higher the breakage of proteins in smaller peptides; however, the hydrolysis degree control must be strict, since very high values might damage the hydrolysates functional properties (Kristinsson \& Rasco, 2000). The ultrasound, in general, provided the highest hydrolysis degrees, which evidences that its use is beneficial to the process regarding different types of collagen (Vidal et al., 2018). 
Vidal et al.

Table 5. Protein, hydrolysis degree and antioxidant activity average results regarding different collagen hydrolysate samples.

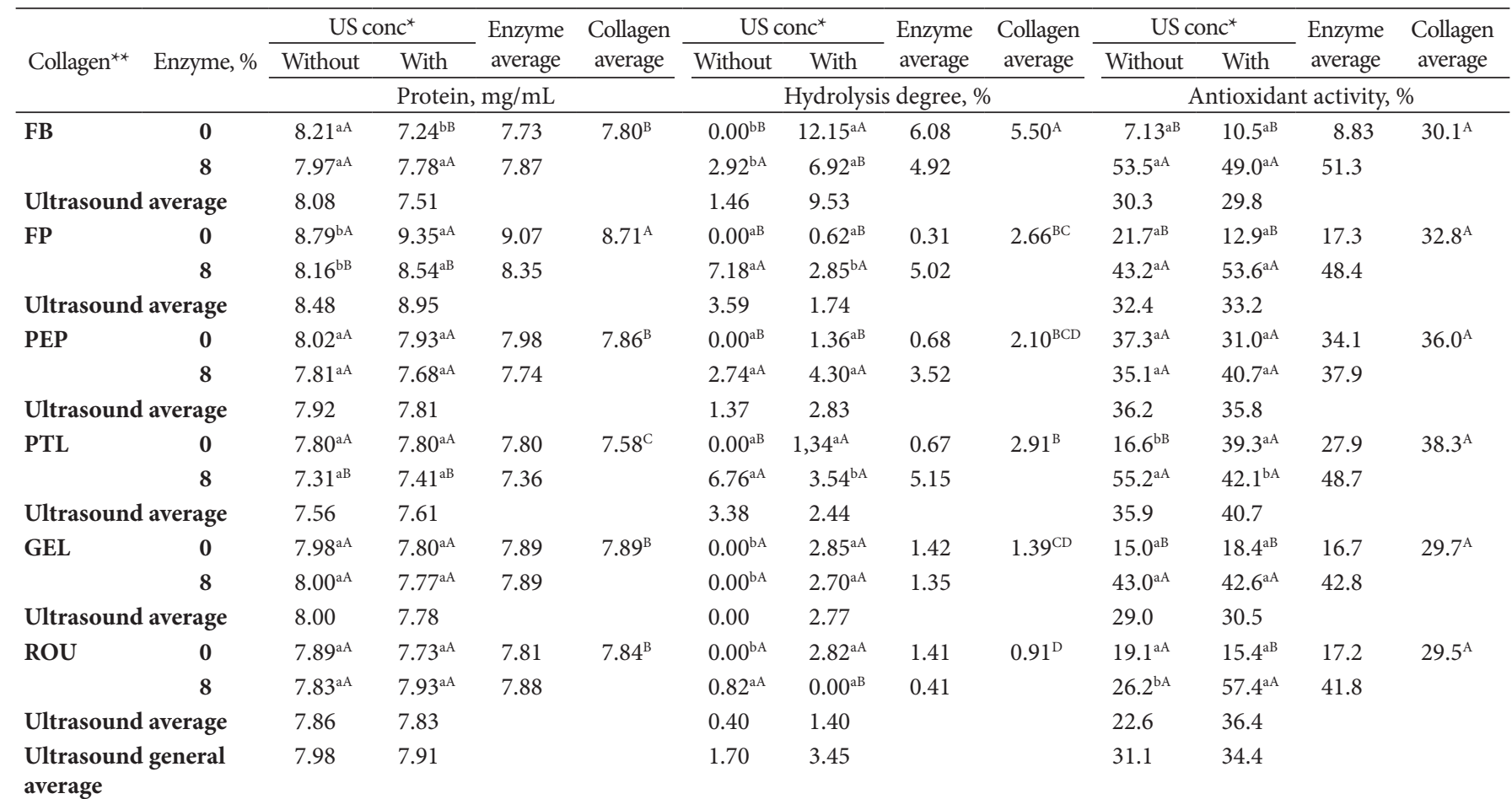

${ }^{* *} \mathrm{FB}$ - collagen fiber; FP - powder collagen fiber; PEP - hydrolyzed 1 collagen; PTL - hydrolyzed 2 collagen; GEL - gelatin 1; ROU - gelatin 2 . ${ }^{\star}$ US conc - simultaneous ultrasound. Averages on the same line with small different letters indicate significant difference between ultrasound with " $\mathrm{t}$ " test ( $\mathrm{p}<0.05)$. Averages on the same column with different capital letters indicate significant difference between enzyme or collagen with " $\mathrm{t}$ " test $(\mathrm{p}<0.05)$.

\subsection{Average results for antioxidant activity in different samples of collagen hydrolysates under the effect of ultrasound vs. enzyme vs. collagen interaction}

Regarding the FB sample, the use of ultrasound in the enzymatic hydrolysis process was not interesting, since it resulted in lower antioxidant activity values or similar values when compared to the absence of ultrasound use (Table 5). In the FP sample, even if the treatments did not present significant differences, the ultrasound provided higher antioxidant activity. The antioxidant activity found by Di Bernardini et al. (2012) for bovine brisket sarcoplasmic protein hydrolysate using the DPPH method of analysis was $18.68 \pm 2.78 \%$.

The use of enzyme in the hydrolysis of previous samples provided higher antioxidant activity values. The ultrasound did not interfere in the PEP and GEL samples antioxidant activity, however, the $8 \%$ enzymatic concentration was seen to generate higher values of antioxidant activity. The antioxidant activity of the PTL sample was higher when only the enzyme was used in the hydrolysis process. For the antioxidant activity of the ROU sample treated with $8 \%$ enzyme the ultrasound helped to obtain higher activity values.

Kangsanant et al. (2014) employed ultrasound treatments in a similar way of this study. The authors studied the use of high intensity ultrasound as pre-treatment and simultaneous to the hydrolysis of tilapia (pseudocrenilabrinae) muscle protein with the enzyme Flavourzyme ${ }^{\circledR}$ and its effect on the bioactivity of the hydrolysates obtained, such as the antioxidant and anti-inflammatory activities. Conversely to this study, the pre-treatment with high intensity ultrasound (70 W), 30 and 40 minutes, combined with conventional hydrolysis was shown the ideal condition to produce tilapia (pseudocrenilabrinae) hydrolysates with nitric oxide and antioxidant (in vitro) inhibiting activity.

\subsection{Collagen hydrolysates antimicrobial activity}

The samples that were shown more efficient to inhibit the Gram-negative bacteria Salmonella choleraesuiswere FB UEH, PTL EH and ROU EHU, with 20\% sample concentration, and regarding the Gram-positive bacteria Staphylococcus aureus were FB EHU, PEP EHU and ROU EH with 17.5\% sample concentration (results not shown). The use of ultrasound in the hydrolysis process favored the antimicrobial activity, which might be explained by better peptide and bacterial cellular membrane bond, inhibiting the micro-organism growth. In a study carried out by Rocha et al. (2014), testing films based on anchoita (Engraulis anchoita) protein along with organic acids to combat the bacteria Staphylococcus aureus, a zone of inhibition of the micro-organism was not found, unlike this study. The micro-organism might use nitrogen present in amino acids as a source of nutrients, with metabolism of nucleotides, peptides and complex proteins. The enzyme secreted by bacteria might hydrolyze a wide variety of protein substrates. In a study by Vidal et al. (2018) the collagen hydrolyzates showed inhibition against Gram-negative bacteria Salmonella choleraesuis and Gram-positive bacteria Staphylococcus aureus. 


\section{Conclusion}

The ultrasound was beneficial to the collagen structural hydrolysis. Simultaneous ultrasound and the $8 \%$ enzymatic concentration were shown most efficient in the sample hydrolysis process, conferring the best hydrolysis degree and antioxidant activity results. The treatment that provided the highest antioxidant activity in the samples PTL and FB was with $8 \%$ enzyme, while in the samples ROU, FP and PEP was the simultaneous ultrasound with $8 \%$ enzyme. The best antioxidant activity results for GEL were obtained with $8 \%$ enzyme regardless of the use of ultrasound. The results pointed out that higher hydrolysis degree not always result in higher antioxidant activity, since values which are too high might damage the hydrolysate functional properties. The use of ultrasound in the hydrolysis process favored the antimicrobial activity. Therefore, we concluded that the ultrasound improved sample hydrolysis, providing higher functionality and structural disruption.

\section{Acknowledgements}

To Fundação de Amparo à Pesquisa do Estado do Rio Grande do Sul (FAPERGS), Conselho Nacional de Desenvolvimento Científico e Tecnológico (CNPq), Novaprom and Rousselot companies. To the Universidade Estadual de Ponta Grossa (UEPG) and Universidade Regional Integrada do Alto Uruguai e das Missões (URI), to CAPES Statute No. 27/2010 - Pro-Equipments Institutional, the Universidade Federal de Santa Maria (UFSM), the coordenação de Aperfeiçoamento de Pessoal de Nível Superior (CAPES) and to the Post-Graduate Program in Food Science and Technology.

\section{References}

Association of Official Analytical Chemists - AOAC. (2016). Official methods of analysis of AOAC International. Maryland: AOAC.

Ashokkumar, M. (2015). Applications of ultrasound in food and bioprocessing. Ultrasonics Sonochemistry, 25, 17-23. http://dx.doi. org/10.1016/j.ultsonch.2014.08.012. PMid:25219872.

Arzeni, C., Martínez, K., Zema, P., Arias, A., Pérez, O. E., \& Pilosof, A. M. R. (2012). Comparative study of high intensity ultrasound effects on food proteins functionality. Journal of Food Engineering, 108(3), 463-472. http://dx.doi.org/10.1016/j.jfoodeng.2011.08.018.

Di Bernardini, R., Harnedy, P., Bolton, D., Kerry, J., O’Neill, E., Mullen, A. M., \& Hayes, M (2011). Antioxidant and antimicrobial peptidic hydrolysates from muscle protein sources and by-products. Food Chemistry, 134(4), 1296-1307. http://dx.doi.org/10.1016/j. foodchem.2010.07.004.

Di Bernardini, R., Mullen, A. M., Bolton, D., Kerry, J., O’Neill, E., \& Hayes, M. (2012). Assessment of the aniotensin-I-converting enzyme (ACE-I) inhibitory and antioxidant activities of hydrolysates of bovine brisket sarcoplasmic proteins produced by papain and characterization of associade bioactive peptidic fractions. Meat Science, 90(1), 226-235. http://dx.doi.org/10.1016/j.meatsci.2011.07.008. PMid:21880436.

Brand-Williams, W., Cuvelier, M. E., \& Berset, C. (1995). Use of a free radical method to evaluate antioxidant activity. Food Science and Technology, 28, 25-30.

Cárcel, J. A., García-Pérez, J. V., Benedito, J., \& Mulet, A. (2012). Food process innovation through new technologies: Use of ultrasound.
Journal of Food Engineering, 110(2), 200-207. http://dx.doi. org/10.1016/j.jfoodeng.2011.05.038.

Decker, E. A., \& Park, Y. (2010). Healthier meat products as functional foods. Meat Science, 86(1), 49-55. http://dx.doi.org/10.1016/j. meatsci.2010.04.021. PMid:20580991.

Demiate, I. M., Dupuy, N., Huvenne, J. P., Cereda, M. P., \& Wosiacki, G. (2000). Relationship between baking behavior of modified cassava starches and starch chermical structure determined by FTIR spectroscopy. Carbohydrate Polymers, 42(2), 149-158. http://dx.doi. org/10.1016/S0144-8617(99)00152-6.

Duan, X., Ocen, D., Wu, F., Li, M., Yang, N., Xu, J., Chen, H., Huang, L., Jin, Z., \& Xu, X. (2014). Purification and characterization of a natural antioxidant peptide from fertilized eggs. Food Research International, 56, 18-24. http://dx.doi.org/10.1016/j.foodres.2013.12.016.

Gaio, I., Saggiorato, A. G., Treichel, H., Cichoski, A. J., Astolfi, V., Cardoso, R. I., Toniazzo, G., Valduga, E., Paroul, N., \& Cansian, R. L. (2015). Antibacterial activity of basil essential oil (OcimumbasilicumL.) in Italian-type sausage. Journal für Verbraucherschutz und Lebensmittelsicherheit, 10(4), 323-329. http://dx.doi.org/10.1007/ s00003-015-0936-X.

Gelita (2014). Certificado de análises. Cotia: Gelita do Brasil Ltda.

Giménez, B., Alemán, A., Montero, P., \& Gómez-Guillén, M. C. (2009). Antioxidant and functional properties of gelatin hydrolysates obtained from skin of sole and squid. Food Chemistry, 114(3), 976-983. http:// dx.doi.org/10.1016/j.foodchem.2008.10.050.

Goméz-Guillén, M. C., Giménez, B., Lopéz-Caballero, M. E., \& Montero, M. P. (2011). Functional and bioactive properties of collagen and gelatin from alternative sources: a review. Food Hydrocolloids, 25(8), 1813-1827. http://dx.doi.org/10.1016/j.foodhyd.2011.02.007.

Herregods, G., Van Camp, J., Morel, N., Ghesquière, B., Gevaert, K., Vercruysse, L., Dierckx, S., Quanten, E., \& Smagghe, G. (2011). Angiotensi I-converting enzyme inhibitory activity of gelatin hidrolysates and identification of bioactives peptides. Journal of Agricultural and Food Chemistry, 59(2), 552-558. http://dx.doi. org/10.1021/jf1037823. PMid:21174470.

Knezevic-Jugovic, Z., Stefanovic, A., Zuza, M., Milovanovic, S., Jakovetic, S., Manojlovic, V., \& Bugarski, B. (2012). Effects of sonication and high-pressure carbon dioxide processingon enzymatic hydrolysis of egg white proteins. Acta Periodica Technologica, 43(43), 33-41. http://dx.doi.org/10.2298/APT1243033K.

Kong, J., \& Yu, S. (2007). Fourier transform infrared spectroscopic analysis of protein secondary structures. Acta Biochimica et Biophysica Sinica, 39(8), 549-559. http://dx.doi.org/10.1111/j.1745-7270.2007.00320.x. PMid:17687489.

Kristinsson, H. G., \& Rasco, B. A. (2000). Fish protein hydrolysates: production, biochemical, and functional properties. Critical Reviews in Food Science and Nutrition, 40(1), 43-81. http://dx.doi. org/10.1080/10408690091189266. PMid:10674201.

Kangsanant, S., Murkovic, M., \& Thongraung, C. (2014). Antioxidant and nitric oxide inhibitory activities of tilapia (Oreochromisniloticus) protein hydrolysate: Effect of ultrasonic pretreatment and ultrasonicassisted enzymatic hydrolysis. International Journal of Food Science \& Technology, 49(8), 1932-1938. http://dx.doi.org/10.1111/ijfs.12551.

Li, B., Chen, F., Xang, X., Ji, B., \& Wu, Y. (2007). Isolation and identification of antioxidative peptides from porcine collagen hydrolysate by consecutive chromatography and eletrospray ionization-mass spectrometry. Food Chemistry, 102(4), 1135-1143. http://dx.doi. org/10.1016/j.foodchem.2006.07.002.

Liu, Z. Y., Oliveira, A. C. M., \& Su, Y. C. (2010). Purification andcharacterization of pepsin-solubilized collagen from skin and 
connective tissue of giant red sea cucumber (Parastichopuscalifornicus). Journal of Agricultural and Food Chemistry, 58(2), 1270-1274. http:// dx.doi.org/10.1021/jf9032415. PMid:20085374.

O’Sullivan, J., Murray, B., Flynn, C., \& Norton, I. (2015). The effect of ultrasound treatment on the structural, physical and emulsifying properties of animal and vegetable proteins. Food Hydrocolloids, 53, 141-154. http://dx.doi.org/10.1016/j.foodhyd.2015.02.009.

Ozuna, C., Paniagua-Martínez, I., Castaño-Tostado, E., Ozimek, L., \& Amaya-Llano, S. L. (2015). Innovative applications of high-intensity ultrasound in the development of functional food ingredients: Production of protein hydrolysates and bioactive peptides. Food Research International, 77, 685-696. http://dx.doi.org/10.1016/j. foodres.2015.10.015.

Pati, F., Adhikari, B., \& Dhara, S. (2010). Isolation and characterization of fish scale collagen of higher thermal stability. Bioresource Technology, 101(10), 3737-3742. http://dx.doi.org/10.1016/j.biortech.2009.12.133. PMid:20116238.

Prestes, R. C., Graboski, A., Roman, S. S., Kempka, A. P., Toniazzo, G., Demiate, I. M., \& Diluccio, M. (2013). Effects of the addition of collagen and degree of comminution in the quality of chicken ham. Journal of Applied Poultry Research Association, 22(4), 885-903. http://dx.doi.org/10.3382/japr.2013-00809.

Rocha, M., Loiko, M. R., Tondo, E. C., \& Prentice, C. (2014). Physical, mechanical and antimicrobial properties of Argentine anchovy (Engraulisanchoita) protein films incorporated with organic acids. Food Hydrocolloids, 37, 213-220. http://dx.doi.org/10.1016/j. foodhyd.2013.10.017.

Rousselot. (2014). Certificado de análise. Amparo: Rousselot Gelatinas do Brasil Ltda.

Sánchez-Moreno, C., Larrauri, J. A., \& Saura-Calixto, F. (1998). A procedure to measure the antiradical efficiency of polyphenols. Journal of the Science of Food and Agriculture, 76(2), 270-276. http://dx.doi.org/10.1002/(SICI)1097-0010(199802)76:2<270::AIDJSFA 945>3.0.CO;2-9.
Schmidt, C. G., \& Salas-Mellado, M. (2009). Influência da ação das enzimas alcalase e flavourzyme no grau de hidrólise das proteínas de carne de frango. Quimica Nova, 32(5), 1144-1150. http://dx.doi. org/10.1590/S0100-40422009000500012.

Sila, A., Alvarez, O. M., Haddar, A., Frikha, F., Dhulster, P., NedjarArroume, N., \& Bougatef, A. (2016). Purification, identification and structural modelling of DPP-IV inhibiting peptides from barbel protein hydrolysate. Journal of Chromatography. B, Analytical Technologies in the Biomedical and Life Sciences, 1008, 260-269. http://dx.doi.org/10.1016/j.jchromb.2015.11.054. PMid:26687732.

Tao, Y., \& Sun, D. W. (2015). Enhancement of food processes by ultrasound: A review. Critical Reviews in Food Science and Nutrition, 55(4), 570-594. http://dx.doi.org/10.1080/10408398.2012.667849 . PMid:24915392.

Vidal, A. R., Cechin, C. F., Cansian, R. L., Mello, R. O., Schmidt, M. M., Demiate, I. M., Kempka, A. P., \& Dornelles, R. C. P. (2018). Enzimatic hydrolysis (pepsin) assisted by ultrasound in the functional properties of hydrolyzates from different collagens. Ciência Rural, 48(3), 3. http://dx.doi.org/10.1590/0103$8478 \mathrm{cr} 20170649$.

Yu, Z. L., Zeng, W. C., Zhang, W. H., Liao, X. P., \& Shi, B. (2014). Effect of ultrasound on the activity and conformation of $\alpha$-amylase, papain and pepsin. Ultrasonics Sonochemistry, 21(3), 930-936. http://dx.doi. org/10.1016/j.ultsonch.2013.11.002. PMid:24291306.

Yu, Z., Zeng, W., \& Lu, X. (2013). Influence of ultrasound to the activity of tyrosinase. Ultrasonics Sonochemistry, 20(3), 805-809. http://dx.doi. org/10.1016/j.ultsonch.2012.11.006. PMid:23207057.

Zielinski, A. A. F., Haminiuk, C. W. I., Nunes, C. A., Schnitzler, E., Van Ruth, S. M., \& Granato, D. (2014). Chemical composition, sensory properties, provenance, and bioactivity of fruti juices as assessed by chemometrics: A critical review and guideline. Comprehensive Reviews in Food Science and Food Safety, 13(3), 300-316. http:// dx.doi.org/10.1111/1541-4337.12060. 